\title{
Monitoring Rainfall Patterns in the Southern Amazon with PERSIANN-CDR Data: Long-Term Characteristics and Trends
}

\author{
Damien Arvor $^{1, *}$ (D), Beatriz M. Funatsu ${ }^{2}$ (D), Véronique Michot ${ }^{1}$ and Vincent Dubreuil ${ }^{1}$ (D) \\ 1 French National Center for Scientific Research (CNRS), Université Rennes 2, UMR LETG, Place du Recteur \\ Henri Le Moal, 354043 Rennes Cedex, France; veronique.michot@univ-rennes2.fr (V.M.); \\ vincent.dubreuil@univ-rennes2.fr (V.D.) \\ 2 CNRS, Université de Nantes, UMR LETG, Campus du Tertre BP 81227, 44312 Nantes Cedex 3, France; \\ beatriz.funatsu@univ-nantes.fr \\ * Correspondence: damien.arvor@univ-rennes2.fr; Tel.: +33-299-141-868
}

Received: 22 May 2017; Accepted: 22 August 2017; Published: 27 August 2017

\begin{abstract}
Satellite-derived estimates of precipitation are essential to compensate for missing rainfall measurements in regions where the homogeneous and continuous monitoring of rainfall remains challenging due to low density rain gauge networks. The Precipitation Estimation from Remotely Sensed Information using Artificial Neural Networks-Climate Data Record (PERSIANN-CDR) is a relatively new product (released in 2013) but that contains data since 1983, thus enabling long-term rainfall analysis. In this work, we used three decades (1983-2014) of PERSIANN-CDR daily rainfall data to characterize precipitation patterns in the southern part of the Amazon basin, which has been drastically impacted in recent decades by anthropogenic activities that exacerbate the spatio-temporal variability of rainfall regimes. We computed metrics for the rainy season (onset date, demise date and duration) on a pixel-to-pixel basis for each year in the time series. We identified significant trends toward a shortening of the rainy season in the southern Amazon, mainly linked to earlier demise dates. This work thus contributes to monitoring possible signs of climate change in the region and to assessing uncertainties in rainfall trends and their potential impacts on human activities and natural ecosystems.
\end{abstract}

Keywords: PERSIANN-CDR; Amazon; rainy season; validation; onset; demise

\section{Introduction}

The Amazon region provides numerous essential ecosystem services, including food production, biodiversity conservation, carbon storage, hydrology and climate regulation [1]. However, in the last few decades, these services have been affected by the expansion of anthropogenic activities that threaten Amazonian ecosystems [2,3]. This issue is particularly significant in the southern and eastern fringes of the basin that have undergone intense land use changes related to the rapid advance of a very dynamic pioneer frontier in the so-called "Arc of deforestation" (e.g., [4-8]).

As a consequence of these rapid changes, the Amazon basin environment is now considered to be in transition to a disturbance-dominated regime [9]. The impacts of deforestation and agricultural development in the Amazon on local [10] and regional [11-13] climate are of particular concern. In addition to the impact of deforestation on global warming through greenhouse gas emissions, particulate emissions and changes in surface fluxes and in the carbon and water cycles ([14] and references therein), changes in rainfall regimes in the Amazon are also of concern [15]. Indeed, Khanna et al. [13] suggested that deforestation is sufficiently advanced to have caused a shift from a thermally- to a dynamically-driven climatic regime, which may affect the rainy season in the 
future. In this connection, previous studies have pointed to intensification of the dry season in the southern Amazon [15-17], and predicted intensification of rainfall during the rainy season [18] or changes in the wet-day and dry-day frequencies [19].

These predictions of climate change need to be confirmed (or refuted) using diverse datasets and methods to better assess the spatio-temporal patterns of precipitation in the Amazon. However, monitoring rainfall in the Amazon is challenging. At the regional scale, rainfall regimes in the Amazon basin are far from uniform [1] and, at a local scale, precipitation is closely linked to the presence of convective cells resulting in marked spatio-temporal variability [11,20]. In this context, the low density of the rain gauge network and the lack of homogeneity in the time series prevent reliable monitoring of this variability using ground data [21-23]. Remote sensing data are thus extremely important since they enable spatially and temporally homogeneous and continuous monitoring of rainfall regimes.

Several remote sensing-based products are available at different spatial and temporal resolutions [23]. For example, the Tropical Rainfall Measuring Mission (TRMM) has provided 3-hourly rainfall estimates at a $0.25^{\circ}$ spatial resolution since 1998 [24]. Although this type of product is useful to capture the fine spatio-temporal variability of precipitation, its use to monitor trends in climate change is debatable due to the relatively short time series (less than 20 years). Beyond the traditional limitations of remote sensing-based rainfall estimates (e.g., [25]), TRMM measurements started in the late 1990s, when deforestation was already rampant in the southern fringes of the Amazon, thus preventing the monitoring of possible changes in precipitation due to changes in land cover and land use. The recent release of Precipitation Estimation from Remotely Sensed Information using Artificial Neural Networks-Climate Data Record CDR data (PERSIANN-CDR) [26,27], consisting of daily rainfall estimates from 1983 to the present, represents a great opportunity to both study precipitation patterns and to assess trends based on more than three decades of data as recommended by the World Meteorological Organization [28,29]. The PERSIANN-CDR product is particularly attractive thanks to the relatively long time series at a fine resolution compared to several other satellite-derived products that have much shorter records, and/or coarser spatial resolution.

While attractive, the PERSIANN-CDR product has been little used to monitor rainfall in the Brazilian Amazon and to identify indicators of climate change. In this context, the objectives of this article are twofold. The first objective is to evaluate the potential of the PERSIANN-CDR data to represent the spatio-temporal precipitation patterns in the southern Amazon through a comparison with rain gauge data. Secondly, an objective is to assess changes in the rainy season in the southern Amazon since the early 1980s by computing three temporal indicators of the rainy season : onset date, demise date and duration.

\section{Study Area}

After a brief qualitative analysis of the potential of the PERSIANN-CDR to reproduce the main rainfall regimes in the entire Amazon, we then focus our study (i.e., quantitative validation of PERSIANN-CDR estimates and analysis of the rainy season parameters) on the southern part of the Amazon basin. This area includes the Brazilian states of Mato Grosso and Rondonia and northern Bolivia (Figure 1). Its climate is characterized by a well-defined rainy season that lasts from September/November to April/May, and is primarily controlled by the South American monsoon system (SAMS) [30-36]. This seasonal behavior is mainly driven by synoptic atmospheric patterns, i.e., (1) the high pressure of the Brazilian and South Atlantic anticyclone from May to September; and (2) the interactions between the Intertropical Convergence Zone and the South Atlantic Convergence Zone during austral summer [37]. Beyond these seasonal mechanisms, rainfall is influenced by: (1) the atmospheric flow of water vapor from the Atlantic Ocean and connections with the Atlantic and Pacific sea surface temperatures [21,38-40]; and (2) a large hydrological recycling process above the forests [41-44]. The large uncertainty of the ocean and continent surface coupling $[39,45,46]$ drives regional and interannual rainfall variability, while the strong heterogeneity of the structure 
and intensity of the convection related to evapotranspiration influences fine/local spatio-temporal variability. The intense land use changes, mainly characterized by high deforestation rates, that have taken place in this pioneer active frontier region in the last four decades partly explain the observed trend toward increased seasonality [20] and a shortening of the rainy season [16,17]. Such trends may have irreversible ecological impacts [44] and affect agricultural activities, which depend on the quantity of rainfall and temporal patterns [15,47-49].

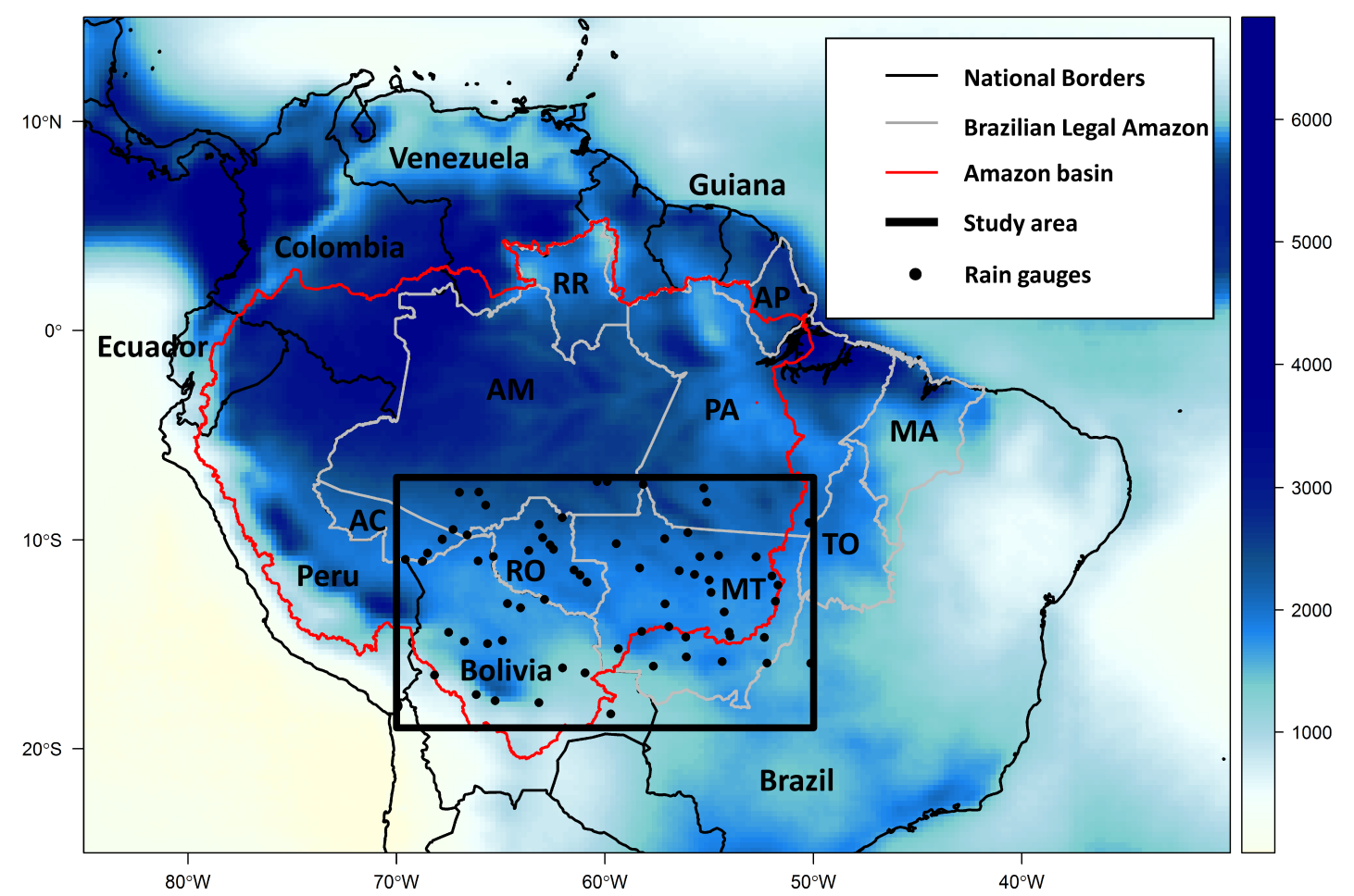

Figure 1. Mean annual rainfall (1983-2014, computed per calendar year) in the Amazon measured using the Precipitation Estimation from Remotely Sensed Information using Artificial Neural Networks-Climate Data Record (PERSIANN-CDR) data with location of the study area (southern Amazon). The acronyms stand for Brazilian states: AC: Acre, AM: Amazonas, AP: Amapa, MA: Maranhão, MT: Mato Grosso, PA: Pará, RO: Rondônia, RR: Roraima, TO: Tocantins.

\section{Data}

\subsection{Rain Gauge Data}

We acquired daily rain gauge datasets from the Brazilian National Water Agency (ANA), the Brazilian National Meteorological Institute (INMET) and the Bolivian Meteorological Service (SENAMHI). We only considered stations for which at least three decades of records between 1983 and 2013 were available, and only stations with less than $20 \%$ missing values were selected. The quality control of the rain gauges consisted in detecting very large and unlikely values resulting from mistakes during the retranscription of data and checking whether a zero value was wrong or not using a nearest neighbor approach. In the end, 71 rain gauges were selected: 57 in Brazil and 14 in Bolivia (Figure 1).

\subsection{PERSIANN-CDR Data}

The Precipitation Estimation from Remotely Sensed Information using Artificial Neural Networks-Climate Data Record (PERSIANN-CDR) product was recently released by the National Oceanic and Atmospheric Administration (NOAA; [26,27]). It consists of daily precipitation estimates 
based on infrared and daytime visible imagery from geostationary satellites, and is built on neural networks classification and approximation techniques [50,51]. The spatial coverage ranges from $60^{\circ} \mathrm{S}$ to $60^{\circ} \mathrm{N}$ and the spatial resolution is of $0.25^{\circ}$ in latitude and in longitude. Data are available for the 1983-delayed present period. For this study we used data for the period 1983-2014.

Ashouri et al. [26] were the first to compare PERSIANN-CDR and rain gauge data at global scale but only a few studies on tropical areas are available to date. The accuracy of PERSIANN-CDR data was recently tested in China by Miao et al. [52] who underlined the potential of PERSIANN-CDR to estimate precipitations in areas where rainfall regimes are related to monsoon systems. Again in China, Yang et al. [53] compared four satellite precipitation products and concluded that the performance of PERSIANN-CDR data is stable over the year, especially because of monthly gauge adjustment. In Malaysia, Tanet al. [54] judged the performance of PERSIANN-CDR to be moderate as it appeared to slightly underestimate extreme precipitation events. Concerning the Amazon, comparisons of PERSIANN (which is a different product to PERSIANN-CDR) and rain gauge data are available [23]. Zubieta et al. [55] showed that PERSIANN data underestimated precipitation in the western Amazon Basin and that its use appeared to be limited for hydrological applications. In contrast, Ringard et al. [56] compared different remote sensing-based rainfall estimation products over French Guiana and North Brazil and highlighted the good performance of PERSIANN-CDR data. More recently, Dubreuil et al. [57] conducted a basic comparison of PERSIANN-CDR and rain gauge data from 13 stations in the Amazon using a point-to-pixel approach and showed that the main precipitation features are well captured by PERSIANN-CDR both at annual and monthly mean time scales.

To summarize, the PERSIANN-CDR data appears relevant to monitor rainfall regimes in the southern Amazon and identify indicators of change in the rainy season due to its good performance in monsoon regions and its long temporal coverage (more than 30 years).

\section{Methods}

\subsection{Validation of PERSIANN-CDR Data in the Southern Amazon}

The first objective of the present study was to assess the accuracy of PERSIANN-CDR data to estimate rainfall in the southern Amazon. To this end, we first performed a qualitative analysis to assess the capacity of PERSIANN-CDR data to capture the spatio-temporal variability of rainfall regimes in the Amazon. We then conducted a quantitative analysis focused on the southern Amazon and based on the comparison of the rainfall measured at rain gauges with the corresponding rainfall estimates based on PERSIANN-DCR data. This comparison was based on continuous and categorical statistical indices as proposed by Tan et al. [54], Miao et al. [52] and Ringard et al. [56].

The continuous indices include the correlation coefficient (CC; Equation (1)), root-mean-square error (RMSE; Equation (2)) and relative bias (RB; Equation (3)). An accurate rainfall estimate is characterized by a high CC combined with low RMSE and $R B$ values. These indices were measured at daily and monthly scales to fully understand the performance of the PERSIANN-CDR data.

$$
\begin{gathered}
C C=\frac{\sum_{i=1}^{n}\left(O_{i}-\bar{O}\right)\left(E_{i}-\bar{E}\right)}{\sqrt{\sum_{i=1}^{n}\left(O_{i}-\bar{O}\right)^{2}} \sqrt{\sum_{i=1}^{n}\left(E_{i}-\bar{E}\right)^{2}}} \\
R M S E=\sqrt{\frac{\sum_{i=1}^{n}\left(E_{i}-O_{i}\right)^{2}}{n}}
\end{gathered}
$$




$$
R B=\frac{\sum_{i=1}^{n}\left(E_{i}-O_{i}\right)}{\sum_{i=1}^{n} O_{i}}(100)
$$

where $E_{i}$ and $O_{i}$ are estimated and observed rainfall respectively at the $i t h$ value of the time series and $n$ is the number of values in the time series.

The categorical indices analyze the capacity of PERSIANN-CDR data to detect rainy days. These indices are accuracy (ACC; Equation (4)), probability of detection (POD; Equation (5)) and false alarm ratio (FAR; Equation (6)). In our case, $A C C$ and $P O D$ must be maximized, while FAR should be minimized.

$$
\begin{aligned}
& A C C=\frac{A+D}{n} \\
& P O D=\frac{A}{A+C} \\
& F A R=\frac{B}{A+B}
\end{aligned}
$$

where $A$ refers to rainfall detected by the rain gauge and the PERSIANN-CDR estimates; $B$ refers to the detection of rainfall by PERSIANN-CDR data when no rainfall was measured at the rain gauge; $C$ refers to precipitation missed by PERSIANN-CDR when rainfall was recorded by the rain gauge; $D$ refers to the non-detection of rainfall both by the rain gauge and by the remote sensing data, and $n$ refers to the total number of observations. In the present study, a rainy day corresponds to a day with estimated rainfall $>0.2 \mathrm{~mm}$, i.e., the minimum rainfall usually measured by a rain gauge.

Finally, we also compared the estimates of onset and demise dates of the rainy season measured by rain gauges and remote sensing data. The comparison was based on the same continuous statistical indices (CC, RMSE, RB). We also plotted the probability density function and the cumulative distribution function of the differences between estimated and observed onset and demise dates in order to see whether the estimated dates fit the values measured at rain gauges.

\subsection{Determination of the Rainy Season Metrics and Their Trends}

The metrics of the rainy season considered in this study were: annual total rainfall, onset date, demise date and duration of the rainy season. These metrics were computed on a pixel-by-pixel basis for each hydrological year of the dataset (1983 to 2013 with the end of year 2013 occurring in 2014). The onset and demise dates and the duration were estimated based on a slightly modified version of the method proposed by Liebmann et al. [33]. Their method involves calculating a quantity called "anomalous accumulation" based on daily annual time series, which start 10 days before the driest month. The "anomalous accumulation" $(A A)$ was calculated as in Equation (7):

$$
A A(d)=\sum_{n=1}^{d}[R(n)-\bar{R}]
$$

where $d$ is the number of days, $R(n)$ is daily rainfall and $\bar{R}$ is average daily rainfall. From this annual time series, the onset (demise) of the rainy season is defined as the day in which $A A$ is minimum (maximum) (Figure 2). In the present method, unlike in the original method of Liebmann et al. [33], possible false rainy season reports were not considered. This simplified version presented less ambiguous values in the Amazon region [22,58]. The duration of the rainy season consists in the number of days between the onset and the demise dates for each pixel.

In addition, the original method involves using different values of $\bar{R}$ for each different year, e.g., a rainy year has a higher $\bar{R}$ value than a dry year which may lead to similar rainy seasons. 
Here, we decided to apply a single threshold across the 31 annual time series (1983-2013) in order to better analyze trends in the rainy season metrics. The value of $\bar{R}$ was thus computed on a pixel-by-pixel basis as the average daily rainfall computed over the entire time series (31 years), i.e., it corresponds to the mean annual rainfall for one pixel divided by 365 days.

\section{A) Rainfall time serie for a 1-year daily rainfall time serie}

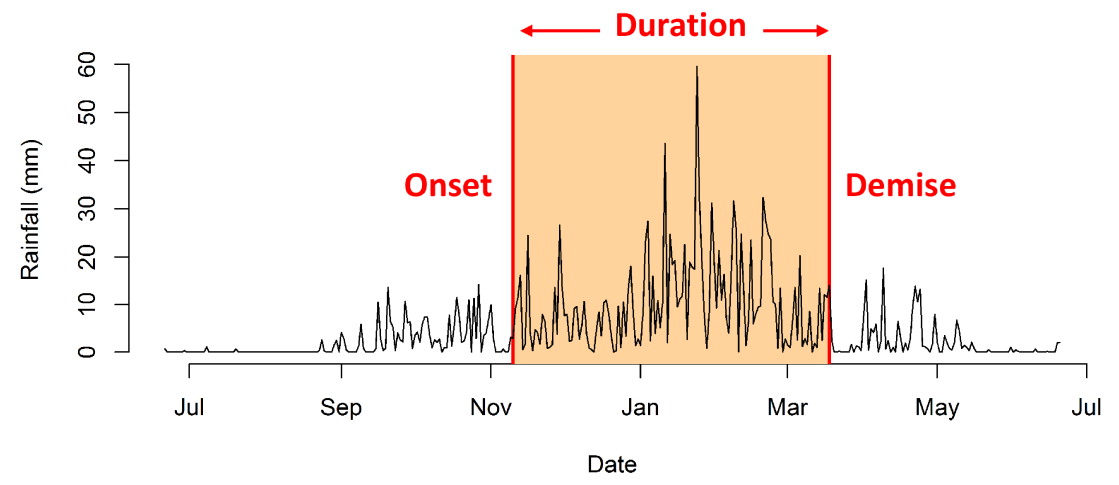

B) Anomalous Accumulation

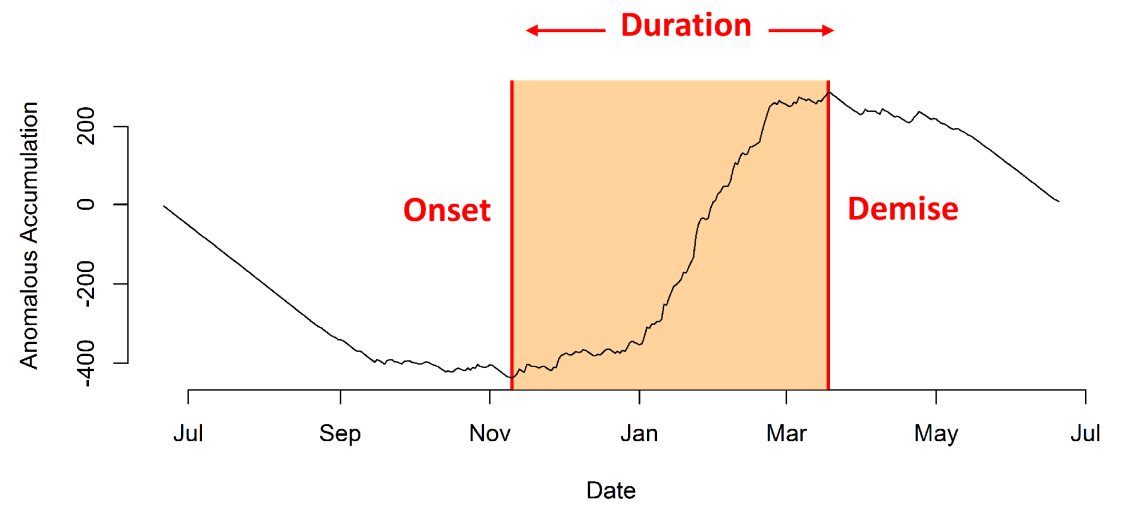

C) Onset and demise dates for a 31-years time series

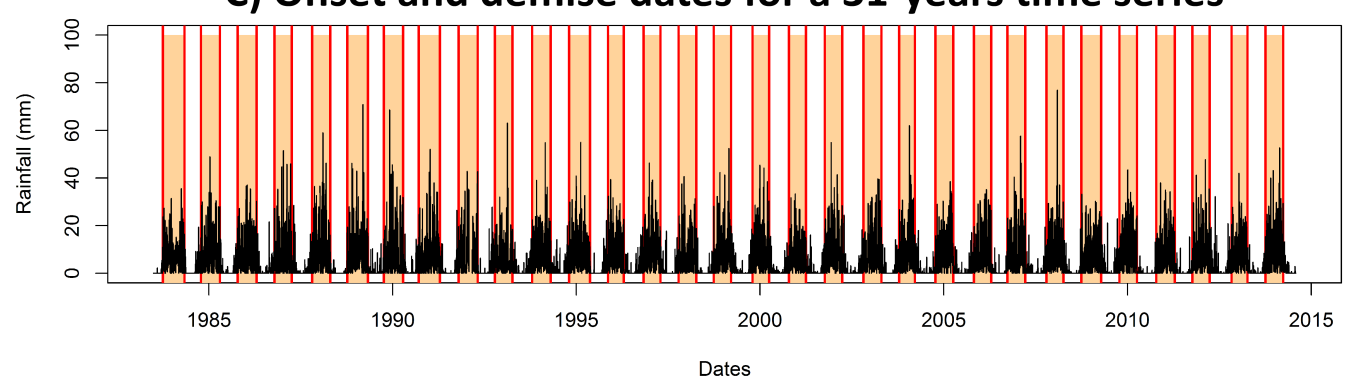

Figure 2. Illustration of the computation of the rainy season temporal metrics based on the method proposed by Liebmann et al. [33]. It includes: (A) a one-year daily rainfall time series for a given pixel; (B) the corresponding anomalous accumulation time series with identified onset and demise dates; (C) the entire (31-year) daily rainfall time series for a given pixel and its corresponding onset and demise dates.

Applying a unique $\bar{R}$ threshold for the entire time series implies that the anomalous accumulation time series computed for dry years tend to decrease continuously since the $\bar{R}$ value is greater than the threshold normally used by Liebmann et al. [33]. As a consequence, the minimum value of the $A A$ time series may occur after the maximum value (or even at the end of the time series), thus leading to inconsistent onset dates that appear to occur after the demise date. To get around this problem, 
we computed the derivative of the AA time series, like in Arvor et al. [47], and identified the middle of the rainy season as the day when this derivative is at a maximum. The onset (demise) date was finally computed as the day of the minimum (maximum) $A A$ value before (after) this middle date.

Moreover, this methodology only makes sense in regions with well-defined rainy and dry seasons. Consequently, we discarded pixels corresponding to areas where the dry season is not clearly defined. The areas to be discarded were determined according to the Köppen classification rules, considering the $A f$ class (equatorial or tropical rainforest climate) where the mean rainfall of the driest month of the year is greater than $60 \mathrm{~mm}$. In this connection, it is worth noting that a few periods of the PERSIANN-CDR data (February 1992, end of March 1993) do not contain rainfall estimates (NA values). For these missing periods, we replaced the NA values with $\bar{R}$ so that they did not lead to the early demise of the rainy season.

Finally, we calculated the averages and trends for each of the four metrics of the rainy season computed over the 1983-2013 time period. Trends were computed based on the Mann-Kendall test (e.g., [22]). Here we present only the coefficient $\tau$ of Mann-Kendall, which varies from -1 to +1 . The value of $-1(+1)$ indicates a trend of continuous decrease (continuous growth) in the study period. The value 0 indicates that there is no trend. Finally, a $p$-value of less than 0.05 was used to assess whether trends were significant.

\section{Results}

\subsection{Validation of PERSIANN-CDR Data}

\subsubsection{Qualitative Analysis}

Figure 1 shows the mean annual rainfall in the Amazon region. The main climatological characteristics were reproduced by the PERSIANN-CDR data. The Equatorial and northwestern regions have the highest rainfall, with more than $3000 \mathrm{~mm}$ per year. Rainfall decreases in the tropical northern and southern latitudes with less than $2000 \mathrm{~mm}$ per year [37,59-61]. In addition, the data made it possible to locate a dry NW-SE "corridor" with precipitation of less than $1500 \mathrm{~mm} /$ year between two high-precipitation regions (>3000 mm), in the Colombia/Venezuela region and along the equatorial coast near French Guiana, and which extends as far south of the Amazon delta as the state of Pará. In the central part of the Amazon, a positive precipitation gradient extends from approximately $\sim 12^{\circ} \mathrm{S}$ up to the Equator (northern boundary of the domain). In the Andean mountains, which are part of the Amazon Basin, rainfall varies greatly depending on the altitude and on the exposure of the slope [62,63]. Generally, air humidity decreases with altitude and annual precipitation is less than $1000 \mathrm{~mm}$ above 3000 masl. Except on windward flanks, precipitation in southern Peru and northern Bolivia can reach $6000 \mathrm{~mm}$ per year. On the contrary, if the slope is leeward, the rainfall may be less than $500 \mathrm{~mm}$ per year $[37,63,64]$.

At a monthly scale, mean precipitation values for the same period (1983-2013) revealed the spatio-temporal variability of rainfall throughout the Amazon basin (Figure 3). While rain falls throughout the year in the northern part of the region, the southern regions show a clear seasonality related to the installation and the withdrawal of the South American monsoon system [36] (see Section 2). Thus, the PERSIANN-CDR realistically captures the main characteristics and annual trends in rainfall in the Amazon. 


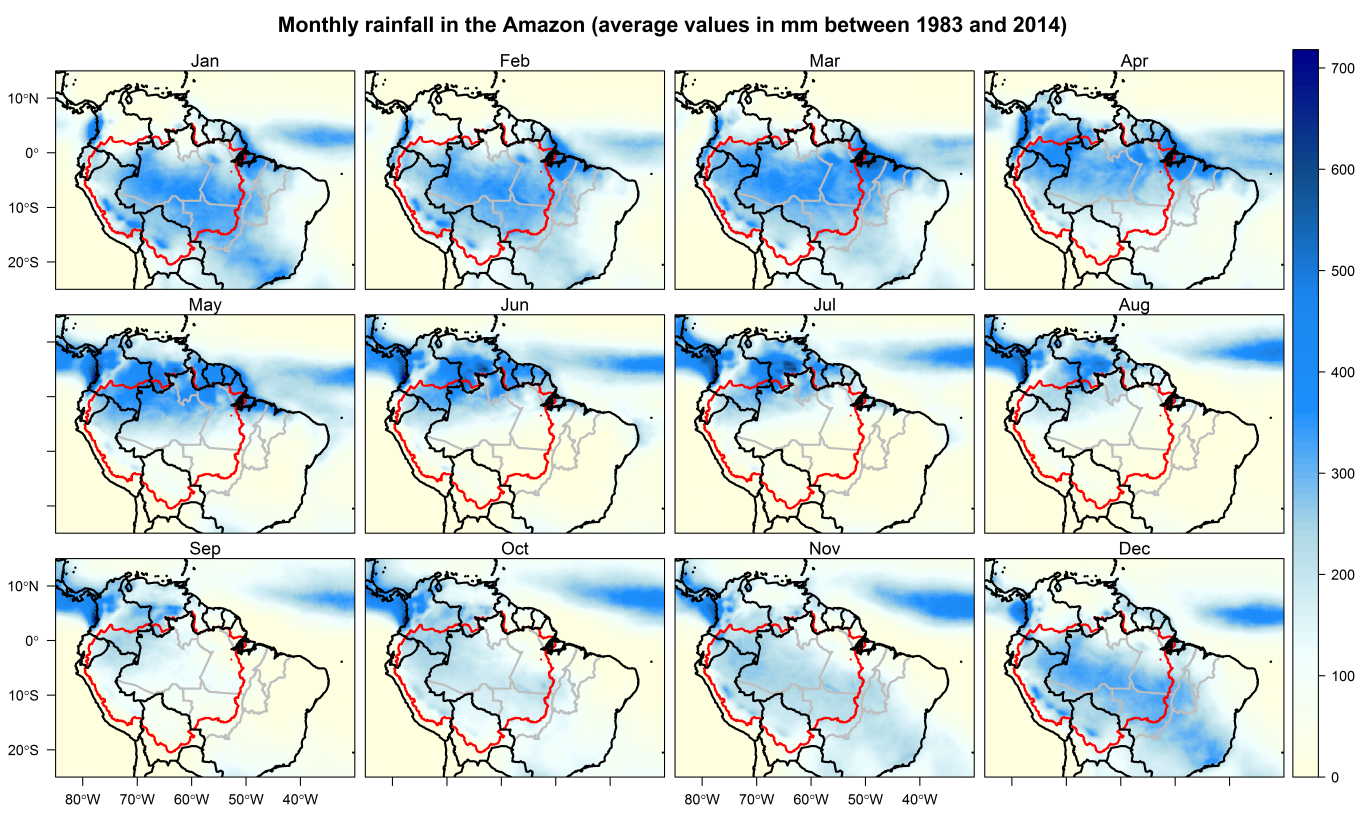

Figure 3. Mean monthly rainfall (mm) in the Amazon basin (red) for the 1983-2014 time period computed from PERSIAN-CDR data.

\subsubsection{Quantitative Analysis}

The results of the quantitative validation of PERSIANN-CDR data are listed in Table 1. At a daily scale, the coefficient correlation was 0.347 and increased to 0.835 at monthly scale (see also [23]). These values underline the difficulty involved in estimating rainfall at a fine temporal scale but confirm the potential of PERSIANN-CDR data to capture rainfall regimes. The relative bias is positive, corresponding to slight (around 6\%) overestimation of remote sensing-based rainfall estimates. Daily statistics computed on a monthly basis emphasize the irregular performance of the PERSIANN-CDR according to the seasons (Figure 4). Correlation and RMSE were better during the dry season (May to September). The relative bias showed rainfall was underestimated during the dry season (especially in June and July) and overestimated in the rainy season. Accuracy (ACC) was also better during the dry season ( $>75 \%$ ) while the months with lowest accuracy (but still greater than $50 \%$ ) were at the beginning (October) and the end (March-April) of the rainy season. On the contrary, the POD was always greater than $50 \%$ but values were lower in the dry season. Finally, consistent with the previous values, the FAR values were lower in the rainy season and higher in the dry season. In July and August, over $75 \%$ of the rainy days detected by PERSIANN-CDR data were in fact not recorded as rainy days by the rain gauges. The contrast between the rainy and dry seasons could be explained by: (1) the type of clouds in winter, with sparsely distributed and less frequent rainy convective clouds (which can lead to a miss at the rain gauge, but are detected by remote sensing data which cover a broader area); (2) the difference in spatial resolution between the two datasets; and (3) the presence of many outliers, some of them due to suspicious rain gauge data $[65,66]$.

Regarding the estimates of the rainy season parameters, the statistical indices (CC, RMSE and RB) were more accurate for demise dates than for onset dates. In addition, PERSIANN-CDR data tended to advance the onset dates (negative bias) and delay the demise dates (positive bias). This bias can also be seen in the scatter plots in Figure 5. The high RMSE values (about 30 days) for both onset and demise dates emphasize the difficulty involved in estimating the rainy season parameters using remote sensing data. Nonetheless, the probability density functions and cumulative distribution functions show that the estimates are well centered (density peak around 0 and cumulative distribution functions characterized by a well-marked logarithmic shape). 
Table 1. Validation results for main statistical indices applied to daily and monthly rainfall values and to onset and demise dates of the rainy season. RMSE: root-mean-square; CC: correlation coefficient; ACC: accuracy; POD: probability of detection; FAR: false alarm ratio.

\begin{tabular}{lcccccc}
\hline & CC & RMSE & Relative Bias & ACC & POD & FAR \\
\hline Daily & 0.347 & 12.122 & 6.058 & 0.618 & 0.913 & 0.430 \\
Monthly & 0.835 & 72.657 & 6.476 & - & - & - \\
\hline Onset date & 0.329 & 31.88 & -3.12 & - & - & - \\
Demise date & 0.434 & 26.58 & 1.26 & - & - & - \\
\hline
\end{tabular}
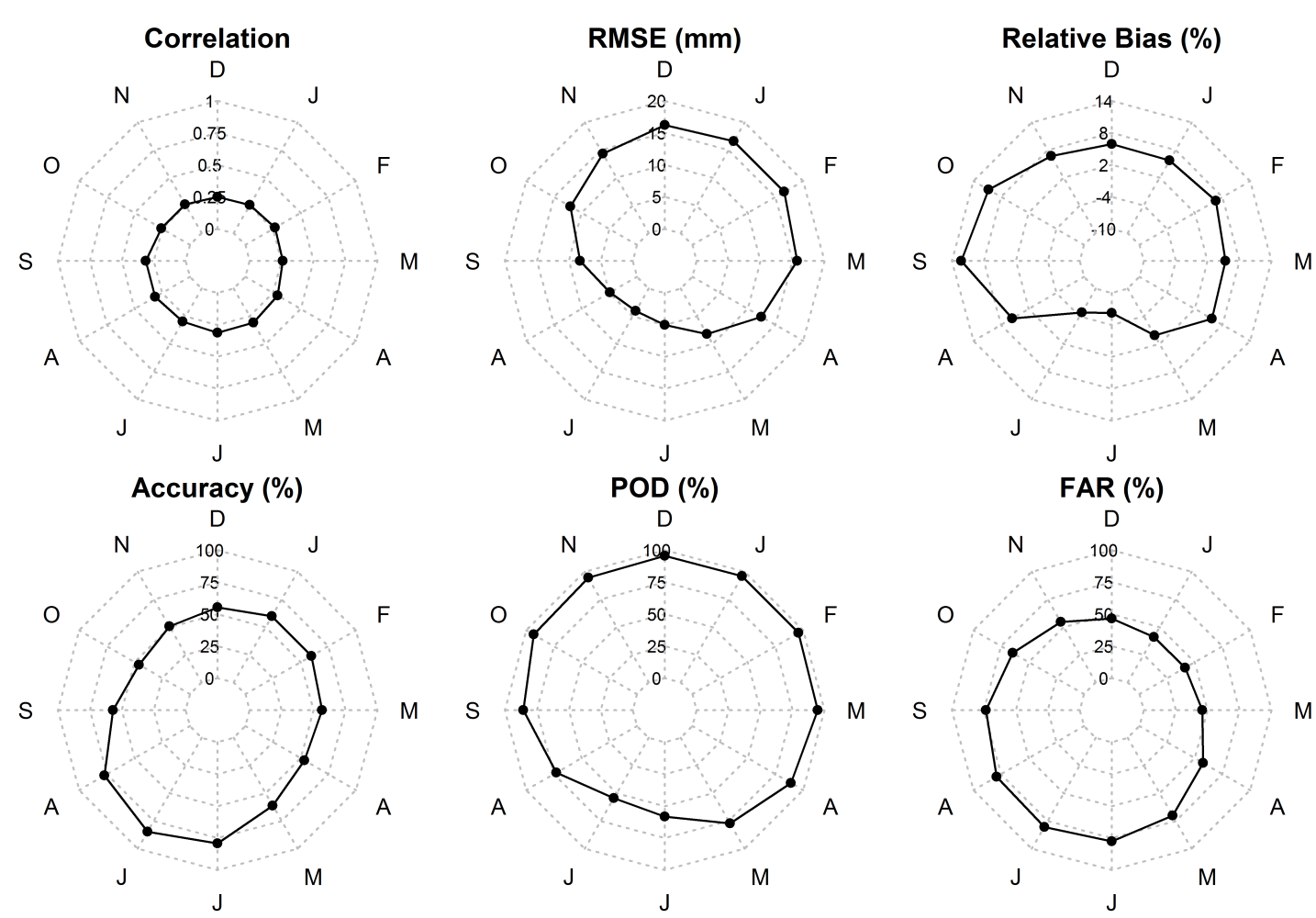

Figure 4. Daily validation statistics of PERSIANN-CDR data computed per month on 71 rain gauges located in the southern Amazon.

Finally, our results are consistent with those of other studies on the validation of PERSIANN-CDR data in other regions of the world $[52,54,56]$ and confirm the interest of testing this dataset to explore potential indices of climate change in the southern Amazon. 
Onset dates (DOY)

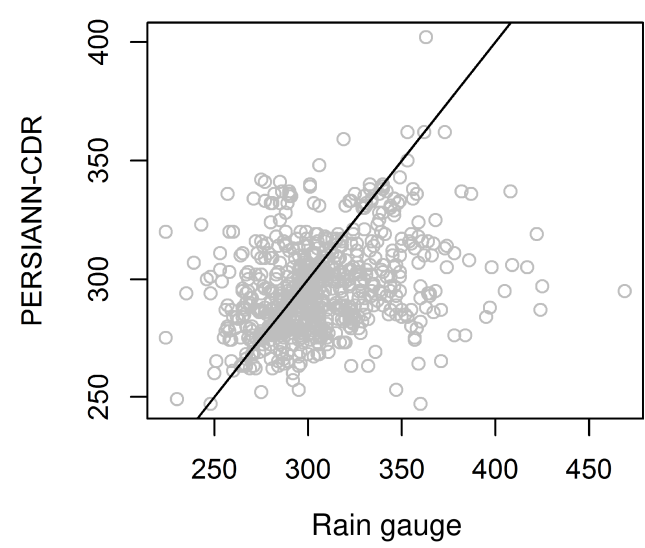

Probability Density Function

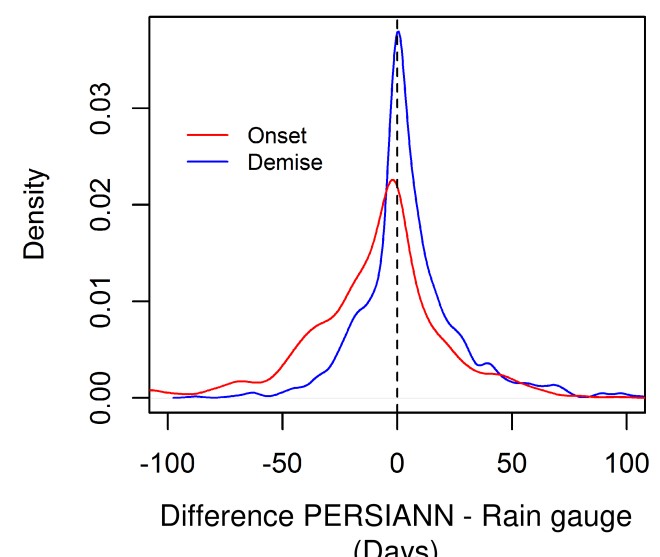

Demise dates (DOY)

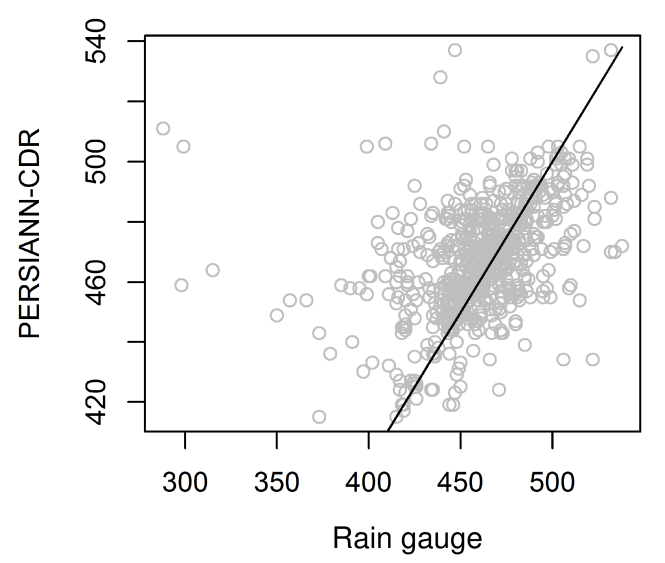

Cumulative Distribution Function

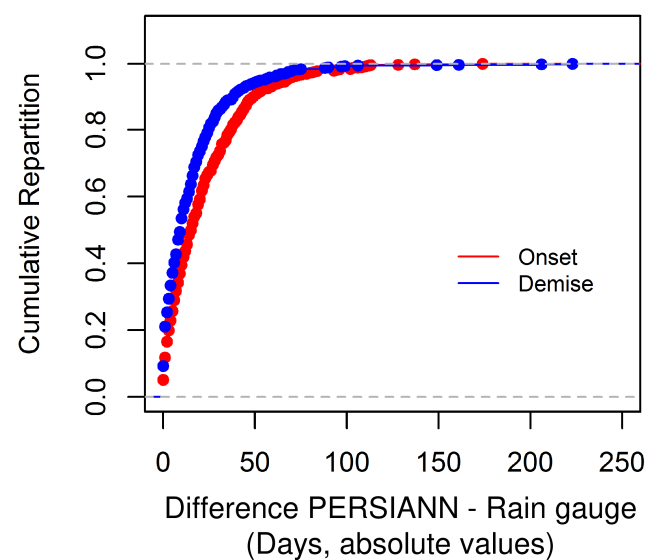

Figure 5. Validation statistics for the onset and demise dates of the rainy season measured by rain gauges and PERSIANN-CDR data. The black line in the two scatter plots represent the identity line.

\subsection{Analysis of Rainy Season Parameters in the southern Amazon}

Beyond the capacity of the PERSIANN-CDR data to estimate rainfall and rainy season metrics in the southern Amazon, we next assessed its potential to capture the large spatial and temporal variability of rainfall regimes and identify possible long-term trends. The results are shown in Figures 6 and 7.

Patterns of annual rainfall are consistent with those found in other studies on rainfall regimes in the Amazon [22,37]. The regions with the highest variability are southern Pará, southern Amazonas and Bolivia (Figure 6, top left). The remote sensing estimates made it possible to highlight specific regions such as the Serra do Cachimbo in southern Pará, which appears to be more rainy than the surrounding areas.

The onset of the rainy season is earlier in northeastern Mato Grosso (MT) and southeastern Pará (Figure 6, top right). The beginning of the rainy season is later in western Mato Grosso (Chapada dos Parecis) compared to other areas of the same state. The differential onset of the rainy season across the state of Mato Grosso described here confirms previous observations and partially explains why double-cropping systems have been less widely adopted in this agricultural region (western Mato Grosso) than in central Mato Grosso [47]. 

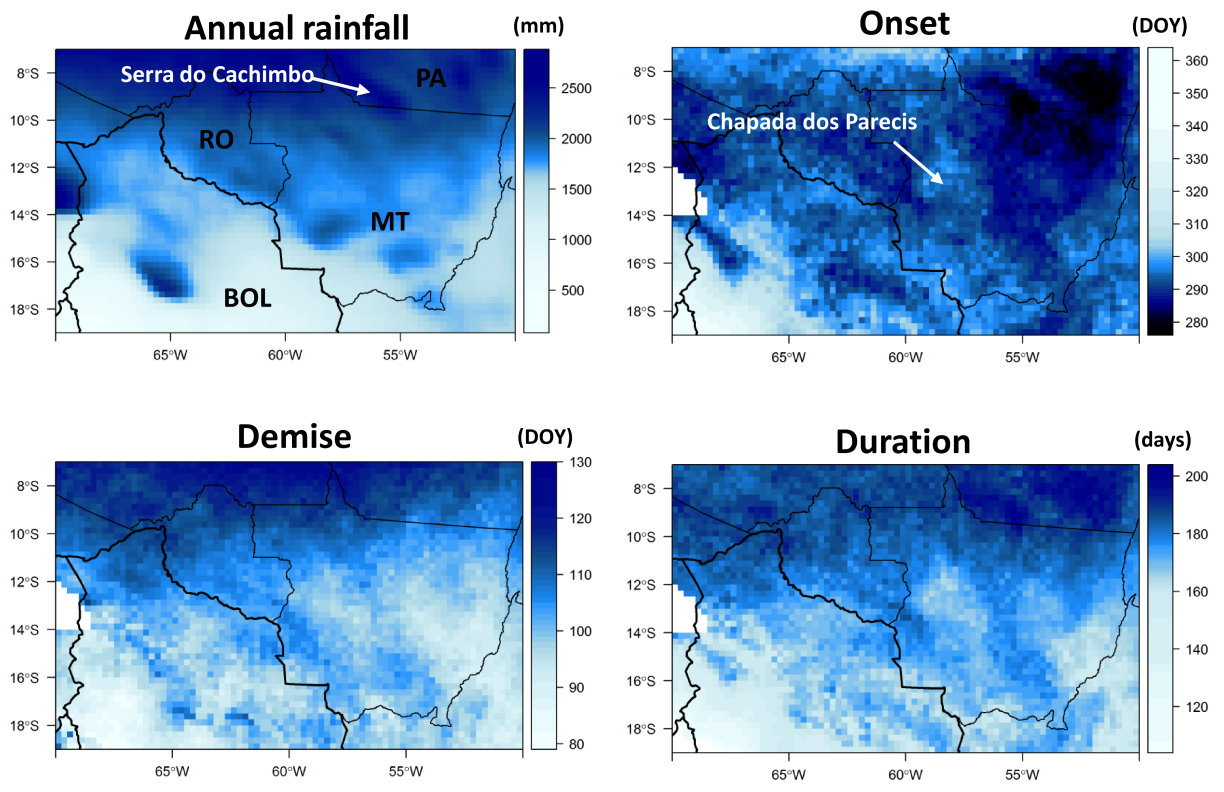

Figure 6. Mean annual rainfall, onset date, demise date and duration of the rainy season in the southern Amazon estimated from PERSIANN-CDR for the 1983-2013 time period. The onset and demise dates are defined as the number of days after 1 January. Areas in white correspond to pixels where the rainy season is not well defined according to the Köppen classification rules. (PA = Pará, MT = Mato Grosso, $\mathrm{RO}=$ Rondônia, $\mathrm{BOL}=$ Bolivia) .
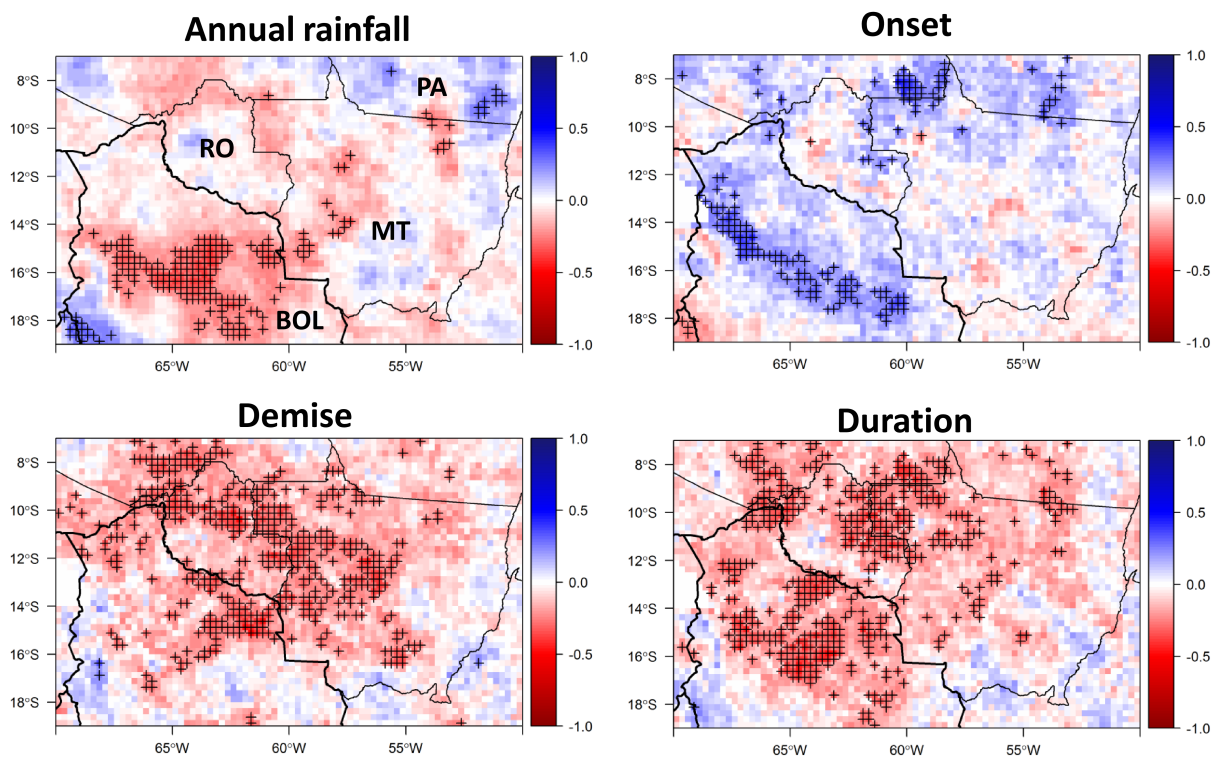

Figure 7. Trends in annual rainfall, onset date, demise date and duration of the rainy season in the southern Amazon estimated from PERSIANN-CDR for the 1983-2013 time period. The trends correspond to the $\tau$ of Mann-Kendall. Significant trends are indicated with crosses. Areas in white correspond to pixels where the rainy season is not well defined according to the Köppen classification rules. $(\mathrm{PA}=$ Pará, $\mathrm{MT}=$ Mato Grosso, $\mathrm{RO}=$ Rondônia, $\mathrm{BOL}=$ Bolivia $)$.

In general, the onset date is characterized by high interannual variability (Figure 8 , top) especially in the northern part of the study area compared to Mato Grosso, which has more pronounced wet/dry seasons (Figure 3). The onset of the rainy season is associated with a rapid increase in specific humidity 
prior to the onset and changes in the horizontal and vertical winds (characteristic of the South American monsoon) that follows the period when temperatures reach their seasonal maximum [31]. In this context, the high variability of onset dates has been directly linked to pre-seasonal conditions during the dry season in the Pacific and South America [46], which modulate moisture availability, atmospheric instability and atmospheric circulation in both low and upper levels.

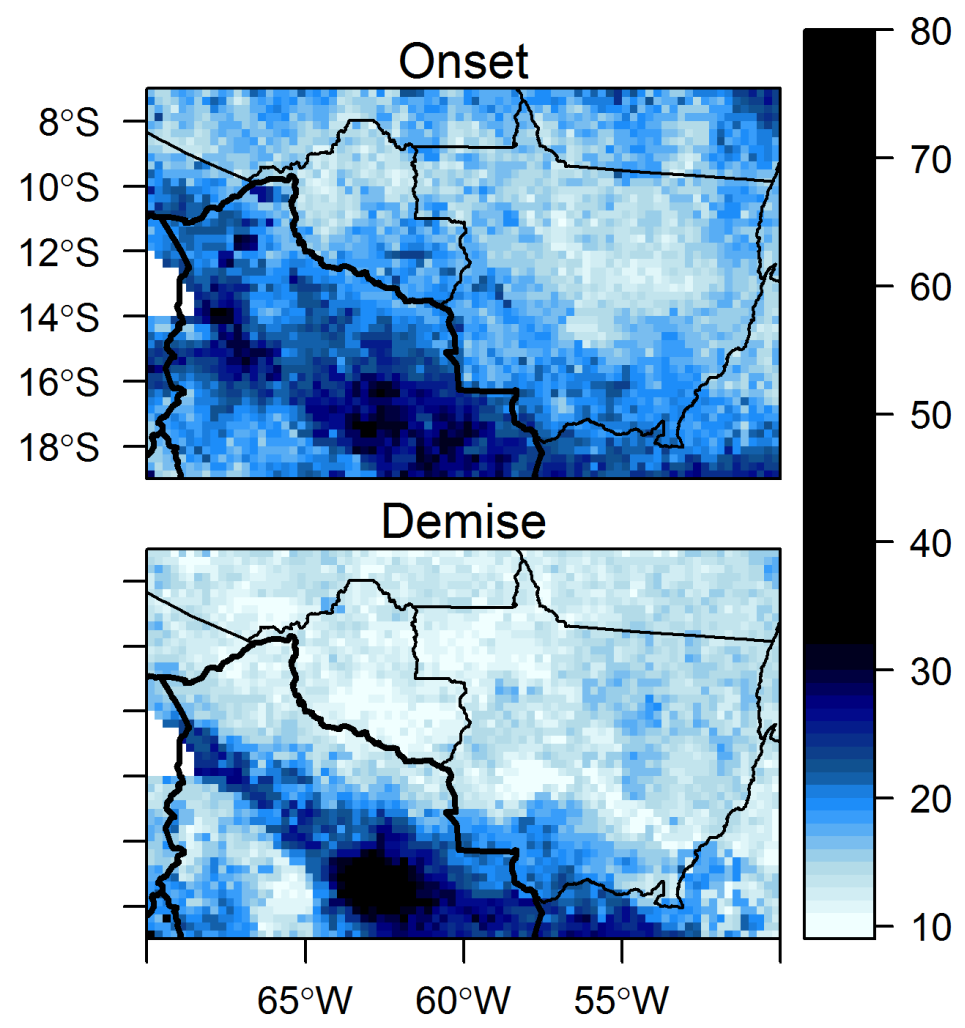

Figure 8. Standard deviation (in days) of onset and demise dates of the rainy season in the southern Amazon.

The demise dates follow a north-south gradient that is more pronounced than for the onset dates (Figure 6, bottom left). The end of the South American monsoon system (SAMS) is linked to the northward migration of the Atlantic ITCZ and the splitting of the mid-latitude upper-level westerly jet into the subtropical and sub-polar jets [30,31]. At lower levels, the north-westerly flux changes to easterlies to the east of the Andes, reducing the moisture supply from the Atlantic over the southern Amazon, thus leading to the demise of the rainy season. In other words, the demise of the rainy season is associated with a strengthening of low-level easterly winds and a general downward motion following the northward displacement of the Hadley cell. Consequently, the interannual variability of demise dates is lower than that of onset dates (Figure 8, bottom). Consistent with these results, the duration of the rainy season is longer in the north than in the south of the study area (Figure 6, bottom right), with greater variability in Bolivia, along the Andean Cordillera, and in the southern and northern parts of the study area (not shown).

Concerning long-term changes in rainfall patterns, annual amounts tend to decrease regionally (Figure 7, top left), although trends vary strongly in the study area and are mainly statistically insignificant, except for regions in Bolivia and western Mato Grosso. In addition, our results indicate positive trends for onset dates (delayed onset) in Bolivia and northern Mato Grosso (Figure 7, top right), but they are mainly significant in Bolivia. Conversely, trends are negative (early onset) in the center of Mato Grosso and in Rondônia but are not significant. Trends in demise dates are significantly negative 
for the majority of the study area including southern Amazonas, parts of Acre and Bolivia, Rondônia, and western Mato Grosso (Figure 7, bottom left), indicating a trend toward earlier demise of the rainy season in these areas. As a consequence, we also observed a trend towards a reduction of the length of the rainy season, with especially significant trends in Bolivia, Rondônia state and southern Amazonas (Figure 7, bottom right).

These observations on the shortening of the rainy season in the southern Amazon are in agreement with results of previous studies $[15,16]$. However, we identified two major cases that appear to coexist with a small overlap: regions where the reduction in the length of the rainy season is linked to delayed onset (mainly central Bolivia) and regions where the reduction is linked to early demise (northern Bolivia, Rondônia, southern Amazonas and western Mato Grosso). This analysis is illustrated (Figure 9, top and bottom plots) by plotting onset and demise dates for the 31-year time series of two areas in Bolivia (with a significant trend toward a shorter rainy season explained by a delayed onset) and in eastern Mato Grosso (with a significant trend toward a shorter rainy season explained by an early demise).
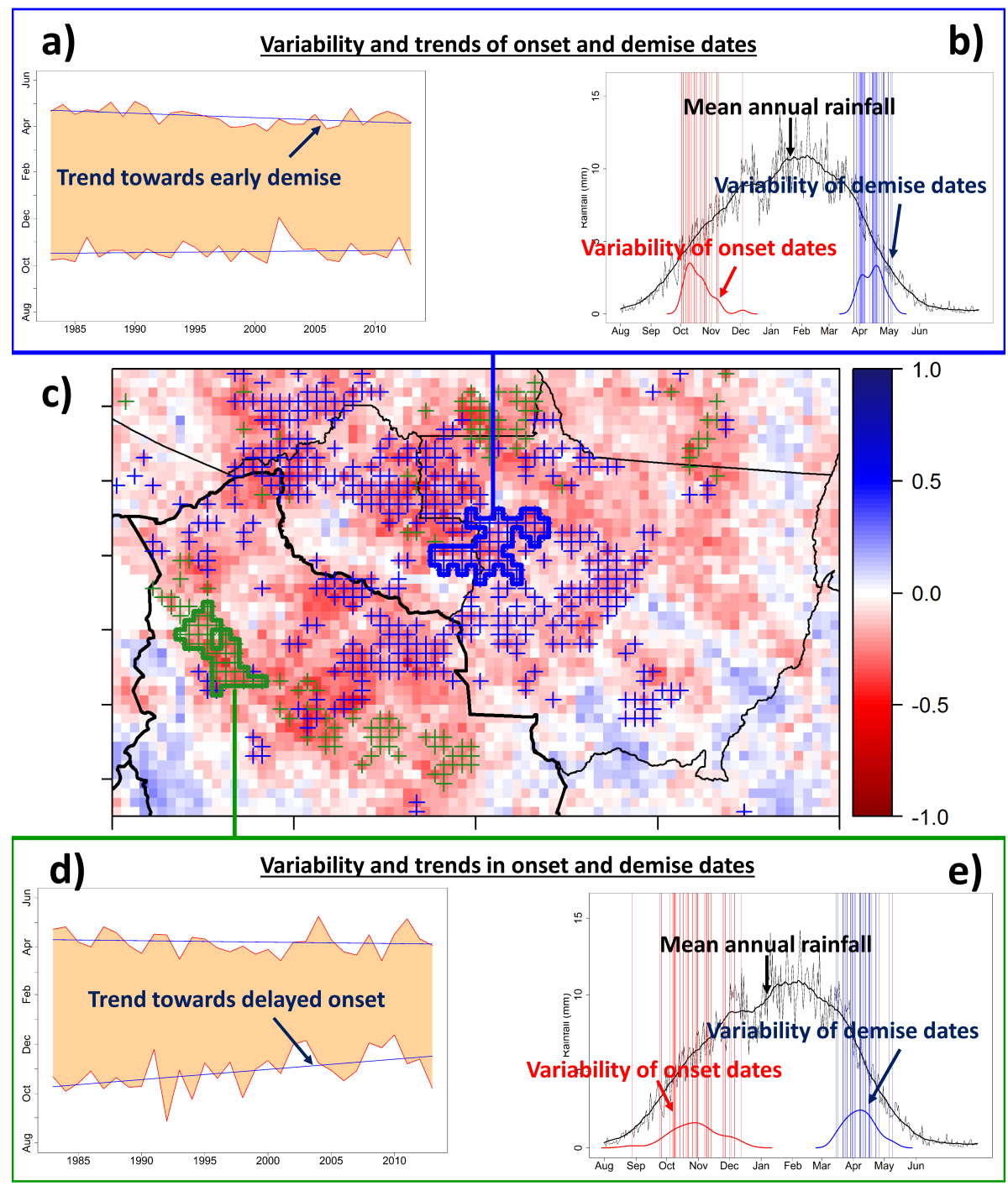

Figure 9. The central map shows trends in the duration of the rainy season ( $\tau$ value) with significant trends of delayed onset (green crosses) and early demise (blue crosses). The top and bottom parts show the 31-year variability and trends for the onset and demise dates at two locations, in Bolivia and at the border between Rondônia and Mato Grosso states. 


\section{Discussion and Future Outlook}

PERSIANN-CDR data were released fairly recently (2013) and have consequently not been widely used for climate change analysis in the Amazon. The results of this pioneer study confirm the good performance of PERSIANN-CDR data for the monitoring of rainfall regimes in areas characterized by monsoon systems [52] and thus validates their interest for this type of application. This study also emphasizes the capacity of remote sensing-based rainfall estimation products to highlight a few subregions such as the Serra do Cachimbo (southern Pará state) or the Chapada dos Parecis (western Mato Grosso state) that do not stand out in studies based on in-situ data. This ability to capture the spatio-temporal variability of rainfall regimes in the Amazon is a major advantage of remote sensing products for fine-scale crop monitoring [67] or hydrological modeling [55,68].

In particular, our results confirm that PERSIANN-CDR estimates can be used for the analysis of onset and demise dates of the SAMS. Generally speaking, these dates are related to a series of dynamic and thermodynamic seasonal changes [31,32,34], including the increase in evapotranspiration linked to the increase in solar radiation in spring, changes in the low and upper-level wind circulations, and the dynamic influence of transient synoptic systems that can trigger large-scale convection. The variability of these factors, modulated by the influences of Pacific and Atlantic sea surface temperatures (SST), affects the variability of onset and demise dates of the rainy season.

In this connection, we found that the standard deviation of the onset dates was much larger than that of the demise dates. This is in agreement with the results obtained by Gan et al. [31] and Gan et al. [32] who used other criteria and atmospheric parameters (wind changes) for the detection of the rainy season. In fact, the large variability and uncertainty concerning the onset data trends is a reflexion of the complex mechanisms that determine the establishment of the monsoon in South America [36]. For example, a southward displacement of the Southern Hemisphere subtropical jet stream due to the influence of El Niño Southern Oscillation (ENSO) conditions could reduce the number of cold front incursions [69] that promote the initiation and organization of large-scale convective processes [31,70]. Additionally, Arias et al. [71] found that a delayed onset of the SAMS was correlated with the accelerated demise of the North Atlantic monsoon, which alters the cross-equatorial flow and prevents the humidity flux necessary to support large-scale organized convection.

The marked variability of demise and especially of onset dates has important implications for the analysis of long-term trends. Our results point to a shortened rainy season due to an early withdrawal of the SAMS. Whether this trend is linked to early weakening of the South American low-level jet/reversal of the low-level winds and/or a greater decrease in the supply of moisture possibly related to deforestation (i.e., less evapotranspiration) was not determined in the present study and requires further investigation. However, this trend is evidence for a shortening of the rainy season which is in agreement with other studies $[16,18]$. However our study indicates a reduction of the rainy season that is more linked to early demise (mainly in Rondônia and western Mato Grosso) rather than to a delayed onset of the rainy season (only observed in Bolivia). This result disagrees with the results of the study of Fu et al. [16] who also observed a shortening of the rainy season but linked it to the delayed onset of the rainy season. We think that these discrepancies may be due to: (1) the large standard deviation of the onset dates that may prevent the identification of statistically robust trends; (2) the use of different datasets; and (3) perhaps most importantly, the different methodologies used to define the rainy season. For example, Fu et al. [16] used temporally (pentads) and spatially (southern Amazon basin)-averaged time series, while we provide a spatial map of the precipitation patterns based on daily data. Further analysis is thus needed to better understand how the trend results may be impacted by the still relatively short time series (31 years). Comparisons with other rainfall data from meteorological stations and/or precipitation products such as the Global Precipitation Climatology Project (GPCP) or the Tropical Rainfall Measuring Mission (TRMM) would be interesting to confirm the trends.

Still from a methodological point of view, the method proposed by Liebmann et al. [33] and applied in the present study merits discussion. Compared to other methods [72,73], its main advantage 
is that it is not based on a subjective threshold fixed arbitrarily. Indeed, the $\bar{R}$ value in Equation (7) can be considered as an adaptive threshold whose value changes depending on the annual time series being studied. Thus, two neighboring pixels or two succeeding annual time series in the same pixel may have different $\bar{R}$ thresholds, which can mean that pixels in dry and humid regions (or different years) may present similar onset and demise dates. While such an approach may be appropriate from a climatological point of view and is easy to implement, it may not be appropriate for other applications. For example, from an agricultural point of view, farmers expect specific rainfall conditions to cultivate crops, e.g., daily precipitation higher than a threshold to start planting soybean or a long rainy season with a minimum average daily precipitation to adopt double cropping systems [47,48]. From this point of view, the adaptive $\bar{R}$ threshold complicates the comparisons between time series of different pixels or years, thus making it difficult to characterize the spatio-temporal variability of the rainy season. In the present study we partially addressed the threshold issue by fixing the $\bar{R}$ based on the entire time series (31 years) for a given pixel, i.e., all annual time series from the same pixel are analyzed based on the same threshold. This enabled us to better capture the long-term trends on a pixel-to-pixel basis. To go even further, we now intend to test the methodology of Liebmann et al. [33] by integrating fixed thresholds in order to reveal new dynamics of the spatio-temporal variability of precipitations in the Amazon.

Finally, the metrics of the rainy season (annual rainfall, onset date, demise date, duration) introduced in this paper do not enable a complete understanding of changes in the rainfall regimes in the Amazon. For example, farmers interviewed in the state of Mato Grosso are worried about the intensification of extremely dry (veranico) or extreme rainfall events during the rainy season that may affect crops or jeopardize the harvest. It is not unusual to have dry periods during the rainy season corresponding to the "break phase" of the SAMS [31,74], and even droughts and floods are part of the natural variability of the system $[75,76]$ and often occur in response to sea-surface temperature (SST) anomalies. However there has been indication of an increasing tendency to extreme seasonal drought or flood occurrences in the Amazon basin $[19,39,77,78]$, including in the southern Bolivian Amazon [40]. An increase in the intensity of the rainfall has also been observed [39] and is predicted by multi-model climate projections [18]. We thus intend to analyze new metrics such as rainfall intensity (e.g., mean daily rainfall, number of rainy days, etc.) and the number and length of extreme events that occur during the rainy season.

\section{Conclusions}

Remote sensing data have long been used to monitor rainfall variability but until recently the short duration of the time series limited the study of climatic trends. We examined the potential of the PERSIANN-CDR data to monitor rainfall variability in the southern Amazon and identify trends in precipitation since the early 1980s. For this purpose, we choose to work on the onset and demise dates of the rainy seasons [33], which appear to be appropriate to monitor the impacts of climate on society [57].

First, we showed that PERSIANN-CDR data can satisfactorily replicate seasonal regimes (monthly CC $=0.835)$ and daily variability $(\mathrm{ACC}=0.61$ ) of rainfall across the southern part of the Amazon Basin. It was also good to estimate the metrics of the rainy season with little tendency to advance the onset dates (negative bias) and delay the demise dates (positive bias). Second, we provide evidence for strong heterogeneity of rainfall trends at a regional level with only some regions showing significant results : delayed onset in Bolivia and early demise in western Mato Grosso and Rondônia. For most of the southern Amazon, we identified a trend toward a shorter rainy season linked to early demise. These results confirm the interest of the PERSIANN-CDR product to monitor climate change. However, it is worth noting that our results differ from those obtained in previous studies whose authors mainly linked the shortening of the rainy season to delayed onset [16]. This difference can be explained by: (1) the different data and methods used; (2) sensitivity to extreme events especially at the beginning or the end of the series; and (3) the larger variability of onset dates compared to demise dates. 
Finally, while the Amazon region plays an important role in regulating climate at regional and global scales, our results confirm that its own future climate remains uncertain. On the one hand, such uncertainty raises important socio-economic questions since the economic development of the Amazon region is widely based on activities that directly depend on climate conditions (agriculture [47,48], hydropower dams [79], ...). On the other hand, these same anthropogenic activities can have drastic impacts on the environment and exacerbate the spatio-temporal variability of rainfall regimes across the basin $[13,15]$. While we focused our analysis on onset/demise dates, we consider that new metrics of the rainy season should be further tested in order to better assess climate change in the Amazon and its links to human activities. In this regard, a special attention should be paid to: (1) the intensification of extreme events (droughts and floods) [39,80]; (2) the impacts of climate change on natural ecosystems [7,44]; and (3) the impacts of climate change on anthropogenic activities, especially agriculture [48].

Acknowledgments: This work was supported by (1) Rennes Métropole, who funded an "Allocation d'Installation Scientifique", and (2) the European Union, which funded the H2020-MSCA-RISE-2015 ODYSSEA project (Project Reference: 691053).

Author Contributions: Damien Arvor and Beatriz Funatsu conceived and designed the experiments; Damien Arvor performed the experiments; all the authors analyzed the results and wrote the paper.

Conflicts of Interest: The authors declare no conflict of interest.

\section{References}

1. Laurance, W.F.; Williamson, G.B. Positive Feedbacks among Forest Fragmentation, Drought, and Climate Change in the Amazon. Conserv. Biol. 2001, 15, 1529-1535.

2. Fearnside, P.M. Soybean cultivation as a threat to the environment in Brazil. Environ. Conserv. 2002, 28, 23-38.

3. Laurance, W.F.; Cochrane, M.A.; Bergen, S.; Fearnside, P.F.; Delamônica, P.; Barber, C.; D’Angelo, S.; Fernandes, T. The Future of the Brazilian Amazon. Science 2001, 291, 438-439.

4. Dubreuil, V.; Bariou, R.; dos Passo, M.; Ferrand, R.; Nedelec, V. Evolution de la frontière agricole dans le Centre Ouest du Mato Grosso. Cah. Agric. 2005, 14, 217-224.

5. Arvor, D.; Dubreuil, V.; Simões, M.; Bégué, A. Mapping and spatial analysis of the soybean agricultural frontier in Mato Grosso, Brazil, using remote sensing data. GeoJournal 2012, 78, 1-18.

6. Morton, D.C.; DeFries, R.S.; Shimabukuro, Y.E.; Anderson, L.O.; Arai, E.; Espirito-Santo, F.D.B.; Freitas, R.; Morisette, J. Cropland expansion changes deforestation dynamics in the southern Brazilian Amazon. Proc. Natl. Acad. Sci. USA 2006, 103, 14637-14641.

7. Brando, P.M.; Balch, J.K.; Nepstad, D.C.; Morton, D.C.; Putz, F.E.; Coe, M.T.; Silverio, D.; Macedo, M.N.; Davidson, E.A.; Nobrega, C.C.; et al. Abrupt increases in Amazonian tree mortality due to drought-fire interactions. Proc. Natl. Acad. Sci. USA 2014, 111, 6347-6352.

8. Arvor, D.; Daugeard, M.; Tritsch, I.; De Mello-Thery, N.A.; Thery, H.; Dubreuil, V. Combining socioeconomic development with environmental governance in the Brazilian Amazon: The Mato Grosso agricultural frontier at a tipping point. Environ. Dev. Sustain. 2016, 1-22, doi:10.1007/s10668-016-9889-1.

9. Davidson, E.A.; de Araujo, A.C.; Artaxo, P.; Balch, J.K.; Brown, I.F.; Bustamante, M.C.M.; Coe, M.T.; DeFries, R.S.; Keller, M.; Longo, M.; et al. The Amazon basin in transition. Nature 2012, 481, 321-328.

10. Dubreuil, V.; Debortoli, N.; Funatsu, B.; Nedelec, V.; Durieux, L. Impact of land-cover change in the Southern Amazonia Climate: A case study for the region of Alta Floresta, Mato Grosso, Brazil. Environ. Mon. Assess. 2012, 184, 877-891.

11. Funatsu, B.M.; Dubreuil, V.; Claud, C.; Arvor, D.; Gan, M.A. Convective activity in Mato Grosso state (Brazil) from microwave satellite observations: Comparisons between AMSU and TRMM data sets. J. Geophys. Res. Atmos. 2012, 117, doi:10.1029/2011JD017259.

12. Swann, A.L.; Longo, M.; Knox, R.G.; Lee, E.; Moorcroft, P.R. Future deforestation in the Amazon and consequences for South American climate. Agric. For. Meteorol. 2015, 214-215, 12-24.

13. Khanna, J.; Medvigy, D.; Fueglistaler, S.; Walko, R. Regional dry-season climate changes due to three decades of Amazonian deforestation. Nat. Clim. Chang. 2017, 7, 200-204. 
14. Longobardi, P.; Montenegro, A.; Beltrami, H.; Eby, M. Deforestation Induced Climate Change: Effects of Spatial Scale. PLOS ONE 2016, 11, doi:10.1371/journal.pone.0153357.

15. Nobre, C.A.; Sampaio, G.; Borma, L.S.; Castilla-Rubio, J.C.; Silva, J.S.; Cardoso, M. Land-use and climate change risks in the Amazon and the need of a novel sustainable development paradigm. Proc. Natl. Acad. Sci. USA 2016, 113, 10759-10768.

16. Fu, R.; Yin, L.; Li, W.; Arias, P.A.; Dickinson, R.E.; Huang, L.; Chakraborty, S.; Fernandes, K.; Liebmann, B.; Fisher, R.; et al. Increased dry-season length over southern Amazonia in recent decades and its implication for future climate projection. PNAS 2013, 110, 18110-18115.

17. Boisier, J.P.; Ciais, P.; Ducharne, A.; Guimberteau, M. Projected strengthening of Amazonian dry season by constrained climate model simulations. Nat. Clim. Chang. 2015, 5, 656-660.

18. Cook, B.; Zeng, N.; Yoon, J.H. Will Amazonia dry out? Magnitude and causes of change from IPCC climate model projections. Earth Interact. 2012, 16, 1-27.

19. Espinoza, J.C.; Segura, H.; Ronchail, J.; Drapeau, G.; Gutierrez-Cori, O. Evolution of wet-day and dry-day frequency in the western Amazon basin: Relationship with atmospheric circulation and impacts on vegetation: Wet-Day \& Dry-Day Frequency in Amazon and Impacts on Vegetation. Water Resour. Res. 2016, $52,8546-8560$.

20. Durieux, L. The impact of deforestation on cloud cover over the Amazon arc of deforestation. Remote Sens. Environ. 2003, 86, 132-140.

21. Ronchail, J.; Cochonneau, G.; Molinier, M.; Guyot, J.L.; De Miranda Chaves, A.G.; Guimarães, V.; de Oliveira, E. Interannual rainfall variability in the Amazon basin and sea-surface temperatures in the equatorial Pacific and the tropical Atlantic Oceans. Int. J. Climatol. 2002, 22, 1663-1686.

22. Debortoli, N.S.; Dubreuil, V.; Funatsu, B.; Delahaye, F.; de Oliveira, C.; Rodrigues-Filho, S.; Saito, C.H.; Fetter, R. Rainfall patterns in the Southern Amazon: A chronological perspective (1971-2010). Clim. Chang. 2015, 132, 1-20.

23. Delahaye, F.; Kirstetter, P.E.; Dubreuil, V.; Machado, L.A.T.; Vila, D.A.; Clark, R., III. A consistent gauge database for daily rainfall analysis over the Legal Brazilian Amazon. J. Hydrol. 2015, 525, 292-304.

24. Huffman, G.J.; Bolvin, D.T.; Nelkin, E.J.; Wolff, D.B.; Adler, R.F.; Gu, G.; Hong, Y.; Bowman, K.P.; Stocker, E.F. The TRMM Multisatellite Precipitation Analysis (TMPA): Quasi-Global, Multiyear, Combined-Sensor Precipitation Estimates at Fine Scales. J. Hydrometeorol. 2007, 8, 38-55.

25. Getirana, A.; Espinoza, J.; Ronchail, J.; Rotunno Filho, O. Assessment of different precipitation datasets and their impacts on the water balance of the Negro River basin. J. Hydrol. 2011, 404, 304-322.

26. Ashouri, H.; Hsu, K.L.; Sorooshian, S.; Braithwaite, D.K.; Knapp, K.R.; Cecil, L.D.; Nelson, B.R.; Prat, O.P. PERSIANN-CDR Daily Precipitation Climate Data Record from multisatellite observations for hydrological and climate studies. Bull. Am. Meteorol. Soc. 2015, 96, 69-83.

27. Sorooshian, S.; Hsu, K.; Braithwaite, D.; Ashouri, H.; NOAA CDR Program. NOAA Climate Data Record (CDR) of Precipitation Estimation from Remotely Sensed Information using Artificial Neural Networks (PERSIANN-CDR), Version 1 Revision 1 [1983-2008]; NOAA National Centers for Environmental Information: Asheville, NC, USA, 2014.

28. World Meteorological Organization (WMO). Calculation of Monthly and Annual 30-Year Standard Normals; World Meteorological Organization: Washington, DC, USA, 1989.

29. World Meteorological Organization (WMO). Guide des Pratiques Climatologiques; Technical Report; World Meteorological Organization: Washington, DC, USA, 2011.

30. Zhou, J.; Lau, K.M. Does a Monsoon Climate Exist over South America? J. Clim. 1998, 11, 1020-1040.

31. Gan, M.A.; Kousky, V.E.; Ropelewski, C.F. The South America Monsoon Circulation and Its Relationship to Rainfall over West-Central Brazil. J. Clim. 2004, 17, 47-66.

32. Gan, M.A.; Rao, V.B.; Moscati, M.C.L. South American monsoon indices. Atmos. Sci. Lett. 2005, 6, $219-223$.

33. Liebmann, B.; Camargo, S.J.; Seth, A.; Marengo, J.A.; Carvalho, L.M.V.; Allured, D.; Fu, R.; Vera, C.S. Onset and end of the rainy season in South America in observations and the ECHAM 4.5 Atmospheric General Circulation Model. J. Clim. 2007, 20, 2037-2050.

34. Silva, V.B.S.; Kousky, V.E. The South American Monsoon System: Climatology and Variability. In Modern Climatology; Wang, S.Y.S., Ed.; InTech: Rijeka, Croatia, 2012; pp. 123-152. 
35. Vera, C.; Higgins, W.; Amador, J.; Ambrizzi, T.; Garreaud, R.; Gochis, D.; Gutzler, D.; Lettenmaier, D.; Marengo, J.; Mechoso, C.R.; et al. Toward a Unified View of the American Monsoon Systems. J. Clim. 2006, 19, 4977-5000.

36. Marengo, J.A.; Liebmann, B.; Grimm, A.M.; Misra, V.; Dias, P.L.S.; Cavalcanti, I.F.A.; Carvalho, L.M.V.; Berbery, E.H.; Ambrizzi, T.; Vera, C.S.; et al. Recent developments on the South American monsoon system. Int. J. Climatol. 2012, 32, 1-21.

37. Espinoza Villar, J.C.; Ronchail, J.; Guyot, J.L.; Cochonneau, G.; Naziano, F.; Lavado, W.; De Oliveira, E.; Pombosa, R.; Vauchel, P. Spatio-temporal rainfall variability in the Amazon basin countries (Brazil, Peru, Bolivia, Colombia, and Ecuador). Int. J. Climatol. 2009, 29, 1574-1594.

38. Yoon, J.H.; Zeng, N. An Atlantic influence on Amazon rainfall. Clim. Dyn. 2010, 34, 249-264.

39. Marengo, J.A.; Espinoza, J.C. Extreme seasonal droughts and floods in Amazonia: Causes, trends and impacts: Extremes in Amazonia. Int. J. Climatol. 2016, 36, 1033-1050.

40. Molina-Carpio, J.; Espinoza, J.C.; Vauchel, P.; Ronchail, J.; Caloir, B.G.; Guyot, J.L.; Noriega, L. Hydroclimatology of the Upper Madeira River basin: spatio-temporal variability and trends. Hydrol. Sci. J. 2017, 62, 911-927.

41. Salati, E.; Dall'Olio, A.; Matsui, E.; Gat, J.R. Recycling of water in the Amazon Basin: An isotopic study. Water Resour. Res. 1979, 15, 1250-1258.

42. Makarieva, A.M.; Gorshkov, V.G.; Sheil, D.; Nobre, A.D.; Li, B.L. Where do winds come from? A new theory on how water vapor condensation influences atmospheric pressure and dynamics. Atmos. Chem. Phys. 2013, 13, 1039-1056.

43. Boers, N.; Marwan, N.; Barbosa, H.M.J.; Kurths, J. A deforestation-induced tipping point for the South American monsoon system. Sci. Rep. 2017, 7, doi:10.1038/srep41489.

44. Zemp, D.C.; Schleussner, C.F.; Barbosa, H.M.J.; Hirota, M.; Montade, V.; Sampaio, G.; Staal, A.; Wang-Erlandsson, L.; Rammig, A. Self-amplified Amazon forest loss due to vegetation-atmosphere feedbacks. Nat. Commun. 2017, 8, doi:10.1038/ncomms14681.

45. Liebmann, B.; Marengo, J. Interannual Variability of the Rainy Season and Rainfall in the Brazilian Amazon Basin. J. Clim. 2001, 14, 4308-4318.

46. Yin, L.; Fu, R.; Zhang, Y.F.; Arias, P.A.; Fernando, D.N.; Li, W.; Fernandes, K.; Bowerman, A.R. What controls the interannual variation of the wet season onsets over the Amazon? J. Geophys. Res. Atmos. 2014, 119, 2314-2328.

47. Arvor, D.; Dubreuil, V.; Ronchail, J.; Simões, M.; Funatsu, B.M. Spatial patterns of rainfall regimes related to levels of double cropping agriculture systems in Mato Grosso (Brazil): Spatial patterns of rainfall regimes in Mato Grosso. Int. J. Climatol. 2014, 34, 2622-2633.

48. Cohn, A.S.; VanWey, L.K.; Spera, S.A.; Mustard, J.F. Cropping frequency and area response to climate variability can exceed yield response. Nat. Clim. Chang. 2016, 6, 601-604.

49. Arvor, D.; Tritsch, I.; Barcellos, C.; Jegou, N.; Dubreuil, V. Land use sustainability on the South-Eastern Amazon agricultural frontier: Recent progress and the challenges ahead. Appl. Geogr. 2017, 80, 86-97.

50. Hsu, K.; Gao, X.; Sorooshian, S.; Gupta, H.V. Precipitation estimation from remotely sensed information using artificial neural networks. J. Appl. Meteorol. Climatol. 1997, 36, 1176-1190.

51. Hsu, K.; Gupta, H.V.; Gao, X.; Sorooshian, S. Estimation of physical variables from multichannel remotely sensed imagery using a neural network: Application to rainfall estimation. Water Resour. Res. 1999, 35, 1605-1618.

52. Miao, C.; Ashouri, H.; Hsu, K.L.; Sorooshian, S.; Duan, Q. Evaluation of the PERSIANN-CDR Daily Rainfall Estimates in Capturing the Behavior of Extreme Precipitation Events over China. J. Hydrometeorol. 2015, 16, 1387-1396.

53. Yang, X.; Yong, B.; Hong, Y.; Chen, S.; Zhang, X. Error analysis of multi-satellite precipitation estimates with an independent raingauge observation network over a medium-sized humid basin. Hydrol. Sci. J. 2016, 61, 1813-1830.

54. Tan, M.L.; Gassman, P.W.; Cracknell, A.P. Assessment of Three Long-Term Gridded Climate Products for Hydro-Climatic Simulations in Tropical River Basins. Water 2017, 9, doi:10.3390/w9030229.

55. Zubieta, R.; Getirana, A.; Espinoza, J.C.; Lavado, W. Impacts of satellite-based precipitation datasets on rainfall-runoff modeling of the Western Amazon basin of Peru and Ecuador. J. Hydrol. 2015, 528, 599-612. 
56. Ringard, J.; Becker, M.; Seyler, F.; Linguet, L. Temporal and Spatial Assessment of Four Satellite Rainfall Estimates over French Guiana and North Brazil. Remote Sens. 2015, 7, 16441-16459.

57. Dubreuil, V.; Funatsu, B.M.; Michot, V.; Nasuti, S.; Debortoli, N.; de Mello-Thery, N.A.; Le Tourneau, F.M. Local rainfall trends and their perceptions by Amazonian communities. Clim. Chang. 2017, 143, 461-472.

58. Michot, V.; Dubreuil, V.; Ronchail, J. Variabilité interannuelle des dates de début et de fin de la saison des pluies dans l'arc de déforestation amazonien. In Proceedings of the Actes du 27e Colloque de l'AIC, Dijon, France, 2-5 July 2014; Volume 27, pp. 212-218.

59. Figueroa, S.; Nobre, C.A. A new precipitation distribution over Central and Western Tropical South America. Climanálise 1990, 5, 36-45.

60. Santos, E.B.; Lucio, P.S.; e Silva, C.M.S. Precipitation regionalization of the Brazilian Amazon. Atmos. Sci. Lett. 2015, 16, 185-192.

61. Delahaye, F. Comparative Analysis of Different Satellite Products for Estimation of Precipitation in the Brazilian Amazon. Ph.D. Thesis, Université Rennes 2, Rennes, France, 2013.

62. Roche, M.; Aliaga, A.; Campos, J.; Pena, J.; Cortes, J.; Rocha, N. Hétérogénéité des précipitations sur la cordillère des Andes boliviennes. In Hydrology in Mountainous Regions. I-Hydrological Measurements-The Water Cycle; Lang, H., Musy, A., Eds.; International Association of Hydrological Publishing: Toulouse, France, 1990; Number 193.

63. Ronchail, J.; Gallaire, R. ENSO and rainfall along the Zongo valley (Bolivia) from the Altiplano to the Amazon basin. Int. J.Climatol. 2006, 26, 1223-1236.

64. Espinoza, J.C.; Chavez, S.; Ronchail, J.; Junquas, C.; Takahashi, K.; Lavado, W. Rainfall hotspots over the southern tropical Andes: Spatial distribution, rainfall intensity, and relations with large-scale atmospheric circulation: Rainfall hotspots over the southern tropical Andes. Water Resour. Res. 2015, 51, 3459-3475.

65. Thiemig, V.; Rojas, R.; Zambrano-Bigiarini, M.; Levizzani, V.; De Roo, A. Validation of Satellite-Based Precipitation Products over Sparsely Gauged African River Basins. J. Hydrometeorol. 2012, 13, 1760-1783.

66. Salio, P.; Hobouchian, M.P.; García Skabar, Y.; Vila, D. Evaluation of high-resolution satellite precipitation estimates over southern South America using a dense rain gauge network. Atmos. Res. 2015, 163, 146-161.

67. Gusso, A.; Arvor, D.; Ducati, J.R. Model for soybean production forecast based on prevailing physical conditions. Pesqui. Agropecu. Bras. 2017, 52, 95-103.

68. Wongchuig Correa, S.; de Paiva, R.C.D.; Espinoza, J.C.; Collischonn, W. Multi-decadal Hydrological Retrospective: Case study of Amazon floods and droughts. J. Hydrol. 2017, 549, 667-684.

69. Garreaud, R. Cold Air Incursions over Subtropical South America: Mean Structure and Dynamics. Mon. Weather Rev. 2000, 128, 2544-2559.

70. Li, W.; Fu, R. Influence of Cold Air Intrusions on the Wet Season Onset over Amazonia. J. Clim. 2006, 19, 257-275.

71. Arias, P.A.; Fu, R.; Vera, C.; Rojas, M. A correlated shortening of the North and South American monsoon seasons in the past few decades. Clim. Dyn. 2015, 45, 3183-3203.

72. Marengo, J.A.; Liebmann, B.; Kousky, V.E.; Filizola, N.P.; Wainer, I.C. Onset and End of the Rainy Season in the Brazilian Amazon Basin. J. Clim. 2001, 14, 833-852.

73. Odekunle, T.O. Determining rainy season onset and retreat over Nigeria from precipitation amount and number of rainy days. Theor. Appl. Climatol. 2006, 83, 193-201.

74. Jones, C.; Carvalho, L.M.V. Active and Break Phases in the South American Monsoon System. J. Clim. 2002, 15, 905-914.

75. Lewis, S.L.; Brando, P.M.; Phillips, O.L.; van der Heijden, G.M.F.; Nepstad, D. The 2010 Amazon Drought. Science 2011, 331, 554.

76. Espinoza, J.C.; Ronchail, J.; Guyot, J.L.; Junquas, C.; Drapeau, G.; Martinez, J.M.; Santini, W.; Vauchel, P.; Lavado, W.; Ordoñez, J.; et al. From drought to flooding: Understanding the abrupt 2010-11 hydrological annual cycle in the Amazonas River and tributaries. Environ. Res. Lett. 2012, 7, doi:10.1088/1748-9326/7/2/024008.

77. Gloor, M.; Brienen, R.J.W.; Galbraith, D.; Feldpausch, T.R.; Schöngart, J.; Guyot, J.L.; Espinoza, J.C.; Lloyd, J.; Phillips, O.L. Intensification of the Amazon hydrological cycle over the last two decades. Geophys. Res. Lett. 2013, 40, 1729-1733. 
78. Espinoza Villar, J.C.; Guyot, J.L.; Ronchail, J.; Cochonneau, G.; Filizola, N.; Fraizy, P.; Labat, D.; de Oliveira, E.; Ordonez, J.J.; Philippe, P.V. Contrasting regional discharge evolutions in the Amazon basin (1974-2004). J. Hydrol. 2009, 375, 297-311.

79. Latrubesse, E.M.; Arima, E.Y.; Dunne, T.; Park, E.; Baker, V.R.; d'Horta, F.M.; Wight, C.; Wittmann, F.; Zuanon, J.; Baker, P.A.; et al. Damming the rivers of the Amazon basin. Nature 2017, 546, 363-369.

80. Guimberteau, M.; Ronchail, J.; Espinoza, J.C.; Lengaigne, M.; Sultan, B.; Polcher, J.; Drapeau, G.; Guyot, J.L.; Ducharne, A.; Ciais, P. Future changes in precipitation and impacts on extreme streamflow over Amazonian sub-basins. Environ. Res. Lett. 2013, 8, doi:10.1088/1748-9326/8/1/014035.

(C) 2017 by the authors. Licensee MDPI, Basel, Switzerland. This article is an open access article distributed under the terms and conditions of the Creative Commons Attribution (CC BY) license (http:// creativecommons.org/licenses/by/4.0/). 